\title{
ANALYSIS OF FACTORS THAT AFFECTING THE ACCEPTANCE OF THE USE OF DIGITAL FORM MOBILE APPLICATION AT PT. ABC USING TAM DAN UTAUT THEORETICAL MODEL
}

\author{
Stanley Susanto ${ }^{1}$, Prio Utomo ${ }^{2}$, Kristianus Ade Sudiyono ${ }^{3}$ \\ \{whf.faith93@gmail.com¹, prio.utomo@umn.ac.id², kristianus@lecturer.umn.ac.id ${ }^{3}$ \} \\ Technology Management Department, Universitas Multimedia Nusantara ${ }^{1,2,3}$
}

\begin{abstract}
The use of a digital form mobile application in banking services at PT.ABC, as one of the banking service providers in Indonesia, is not yet popular. In this research, researcher using the TAM-UTAUT models to identify what factors that have a critical influence so that PT. ABC will be able to know what their advantages and disadvantages from digital implementation. Hopefully PT. ABC can optimize services more intensively in their internet banking, so that customers will increasingly believe in the credibility and adaptive ability of banking in this digital era. However, the results obtained also indicate that the technology itself is not a determinant of the successful adoption rate of the use of the digital form mobile application. Thus, it can be concluded that there are other factors outside of technology that affect the acceptance rate of the digital form at PT. ABC itself.
\end{abstract}

Keywords : TAM, UTAUT, Digital form mobile application, internet banking

\section{Introduction}

The rapid development in the technology sector leading to digital banking has pushed one of the divisions at PT. ABC, namely the Digital Service Development Division (DPLD) to develop a digital form mobile application. In fact, the use of the digital form mobile application at PT. ABC is still not experiencing significant improvement. The number of active users every year starting from 2016 was equal to 12,187 , in 2017 equal to 21,544, in 2018 equal to 79,678 and in 2019 equal to 74,739 and if in total there were only 188,148 active users of the digital form mobile application.

In addition of being used as mobile banking and digital payment, the digital form mobile application is focused and optimized to direct their services to digital to satisfy registered customers and attract new customers. However, the digital form mobile application program has proven not quite successful at PT. A B C. Based on existing internal data, the level of customer adoption of the digital form mobile application of PT. ABC is currently relatively low, making it a challenge to create a new digitalbased and customer experience ecosystem.

The identification of the most significant factors for the acceptance and use of the digital form mobile application can at least be a strategic recommendation for PT. ABC to improve the quality of their service to customers. And for general readers, it can be an additional reference regarding the digital form mobile application which is still rarely studied before.

The researcher uses two theoretical models, namely the TAM and UTAUT models. The TAM (Technology Acceptance Model) most often used basic model to measure the adoption rate of new technology systems that can be seen from previous research. However, the measurement of TAM has a drawback, namely the diversity of the variables is few and is only limited to the capabilities of a system without involving the situation of the social roles and surrounding environment that have potential in the adoption of a technology [1]. By combining these two models, it is expected to cover more various fields. This research applied quantitative research to analyze the research object. The initial stage was carried out by distributing questionnaires to selected respondents to obtain validity and reliability 


\section{Literature Review}

With the help from DeLone-McLean model, researcher can make a conclusion that TAM model has limitations because it does not consider social influences in the use and utilization of new existing technologies, so it is necessary to involve the UTAUT theoretical model in it [2].

Furthermore, by combining the TAM and UTAUT theoretical models and using SEM calculations, there are more concrete hypothesis results in generalizing the use of the mobile EMR system to the intention to use of customers in hospitals compared to using only one theoretical model [3].

From the conceptual framework chart above, there are several stages of developing a hypothesis in digital form mobile application research. Starting from the greater the level of perceived trust (PT) of users for an existing system; the more useful the system will be, up to the level of behavioral intention which indicates that the greater the individual's interest in the use of a technology system, the more often the technology system is used.

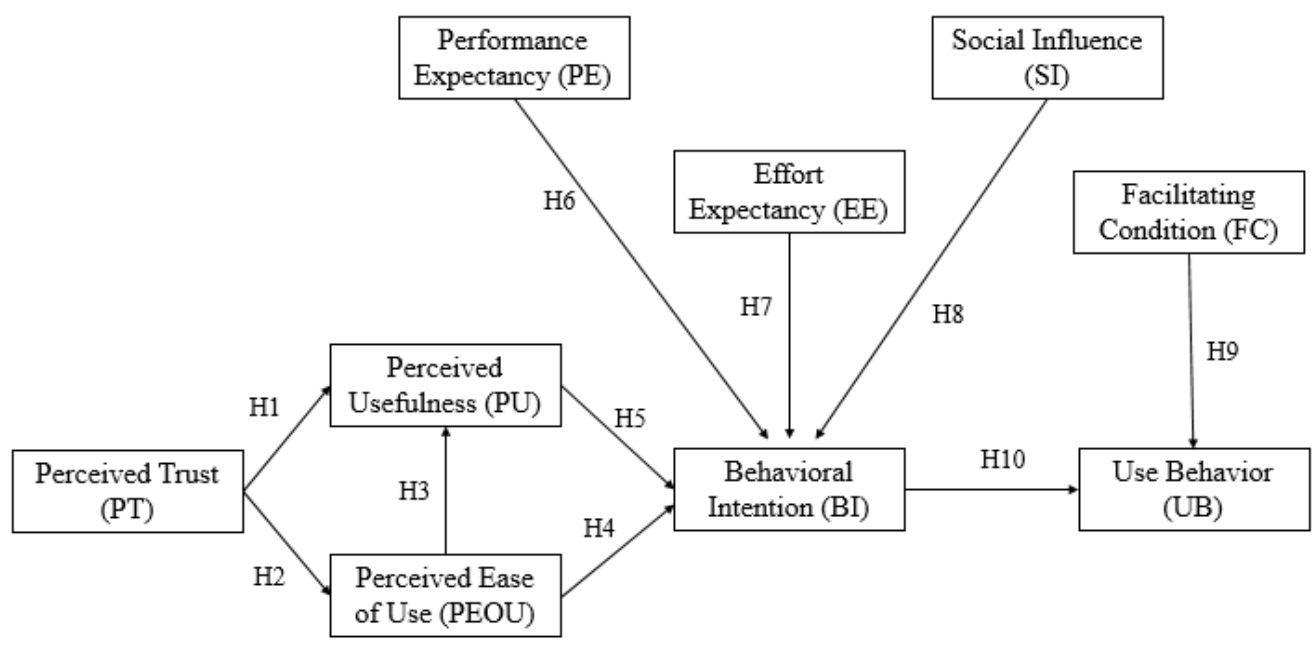

Figure 1 Conceptual Framework

Results :

Source: The Researcher (2020)

$\mathrm{H}_{1}$ : Perceived Trust (PT) has a positive effect towards Perceived Usefulness (PU)

$\mathrm{H}_{2}$ : Perceived Trust (PT) has a positive effect towards Perceived Ease of Use (PEOU)

$\mathrm{H}_{3}$ : Perceived Ease of Use (PEOU) has a positive effect towards Perceived Usefulness (PU)

$\mathrm{H}_{4}$ : Perceived Ease of Use (PEOU) has a positive effect towards Behavioral Intention (BI)

$\mathrm{H}_{5}$ : Perceived Usefulness (PU) has a positive effect towards Behavioral Intention (BI)

$\mathrm{H}_{6}$ : Performance Expectancy (PE) has a positive effect towards Behavioral Intention (BI)

$\mathrm{H}_{7}$ : Effort Expectancy (EE) has a positive effect towards Behavioral Intention (BI)

$\mathrm{H}_{8}$ : Social Influence (SI) has a positive effect towards Behavioral Intention (BI)

$\mathrm{H}_{9}$ : Facilitating Condition (FC) has a positive effect towards Behavioral Intention (BI)

$\mathrm{H}_{10}$ : Behavioral Intention has a positive effect towards Use Behavior (UB)

\section{Methodology and Data Analysis}

\subsection{Methodology}

Taking units, the techniques used, and the sampling process were carried out directly by researchers in the field. Taking the sample unit was processed using a cross-section method with area sampling technique. All units were sampled in one area with only one sampling. Sampling was done by distributing questionnaires to users or users of the digital mobile application form PT. ABC in Jakarta. The results become primary data and then processed using Lisrel 9.2 software through the Partial List Square data analysis technique with its tools, SMART PLS. 


\subsubsection{Operational Variable}

There are five categories in variable operation, consisting of independent variable, intervening variable, dependent variable, by using a Likert scale, and using variable operational tables.

\subsubsection{Data Collecting Technique}

Data collection techniques are divided into two, they are primary and secondary. In primary data, data collection was carried out through interviews with one of the managers of the DPLD division of PT. ABC and distributing questionnaires to sample of respondents using the digital form mobile application at several branch offices of PT. ABC in Jakarta. In the distributed questionnaire screening questions, the researcher also included several elements such as sex, age, latest education, occupation, and frequently used devices.

\subsection{Data Analysis}

There are three analysis techniques that the researcher use. First, the validity test: testing all returned questionnaires as a type of initial evidence. Then, the reliability test which refers to how consistent a test is in measuring the characteristics of the data. In this study, whether the existing parameter value more than the reliability value limit which is 0.600 . If the results from Cronbach's Alpha $>$ from the reliability value limit, the variable is declared reliable (reliable). Finally, the SEM (Structural Equation Model) test is a most often used general statistical modeling technique to measure individual behavior, including conduct a fit test in it.

In this study, the population that used by the researcher are active users of the digital form mobile application at KC PT. ABC which is domiciled in Central Jakarta, West Jakarta, South Jakarta and North Jakarta. After testing the validity and reliability in the first stage, the next stage is to distribute questionnaires by taking samples from the population of active users of the digital application form PT. $\mathrm{ABC}$ of each of the 100 questionnaires at each KC PT. ABC. From that data, it is further divided into several variables according to gender, age, profession, and the most devices used.

Table 1. Demographics of Respondents

\begin{tabular}{|c|c|c|c|}
\hline \multirow{3}{*}{ Gender } & Option & Frequency & $\%$ \\
\hline & Male & 140 & 53 \\
\hline & Female & 125 & 47 \\
\hline \multirow[t]{5}{*}{ Age } & $16-19$ & 5 & 2 \\
\hline & $20-29$ & 106 & 38 \\
\hline & $30-39$ & 127 & 46 \\
\hline & $40-49$ & 35 & 13 \\
\hline & $\geq 50$ & 2 & 1 \\
\hline \multirow[t]{5}{*}{ Degree } & J. High School & 14 & 5 \\
\hline & High School & 103 & 38 \\
\hline & Bachelor & 142 & 52 \\
\hline & Master & 9 & 3 \\
\hline & Doctoral & 5 & 2 \\
\hline \multirow[t]{2}{*}{ Profession } & PNS & 27 & 10 \\
\hline & Private E. & 146 & 53 \\
\hline
\end{tabular}




$\begin{array}{clcr} & \text { Entrepreneur } & 62 & 23 \\ & \text { Housewife } & 9 & 3 \\ \text { Student } & 23 & 8 \\ \text { Others } & 8 & 3 \\ \text { Devices } & \text { Mobile Phone } & 251 & 91 \\ & \text { Tablet } & 6 & 2 \\ & \text { PC } & 3 & 1 \\ \text { Laptop } & \underline{15} & \underline{6}\end{array}$

\section{Research Result and Discussion}

In this research, the researcher used tools Smart PLS 3 in processing the data. the results of the validation and reliability research from the processed data as follows:

\begin{tabular}{|c|c|c|c|c|c|c|c|}
\hline \multirow{3}{*}{ Latent Variable } & \multirow{3}{*}{ Indicators } & \multirow{3}{*}{$\begin{array}{c}\begin{array}{c}\text { Convergent } \\
\text { Validity }\end{array} \\
\text { AVE } \\
>0.50\end{array}$} & \multirow{2}{*}{$\begin{array}{c}\text { Discriminant } \\
\text { Validity } \\
\\
\text { Outer } \\
\text { Loading }\end{array}$} & \multirow{3}{*}{$\begin{array}{c}\text { Model } \\
\text { Evaluation }\end{array}$} & \multicolumn{2}{|c|}{$\begin{array}{c}\text { Internal Consistency } \\
\text { Reliability }\end{array}$} & \multirow{3}{*}{$\begin{array}{c}\text { Model } \\
\text { Evaluation }\end{array}$} \\
\hline & & & & & $\begin{array}{l}\text { Composite } \\
\text { Reliability }\end{array}$ & $\begin{array}{l}\text { Cronbach's } \\
\text { Alpha }\end{array}$ & \\
\hline & & & $>0.60$ & & $>0.60$ & $>0.60$ & \\
\hline \multirow{3}{*}{$\begin{array}{l}\text { Perceived Ease } \\
\text { of Use (PEOU) }\end{array}$} & PEOU1 & \multirow{3}{*}{0.524} & 0.715 & Valid & \multirow{3}{*}{0.766} & \multirow{3}{*}{0.643} & \multirow{3}{*}{ Reliable } \\
\hline & PEOU2 & & 0.644 & Valid & & & \\
\hline & PEOU3 & & 0.803 & Valid & & & \\
\hline \multirow{4}{*}{$\begin{array}{c}\text { Perceived } \\
\text { Usefulness (PU) }\end{array}$} & PU1 & \multirow{4}{*}{0.532} & 0.692 & Valid & \multirow{4}{*}{0.820} & \multirow{4}{*}{0.707} & \multirow{4}{*}{ Reliable } \\
\hline & PU2 & & 0.734 & Valid & & & \\
\hline & PU3 & & 0.773 & Valid & & & \\
\hline & PU4 & & 0.716 & Valid & & & \\
\hline \multirow{3}{*}{$\begin{array}{l}\text { Social Influence } \\
\text { (SI) }\end{array}$} & SI1 & \multirow{3}{*}{0.599} & 0.730 & Valid & \multirow{3}{*}{0.817} & \multirow{3}{*}{0.677} & \multirow{3}{*}{ Reliable } \\
\hline & $\mathrm{SI} 2$ & & 0.800 & Valid & & & \\
\hline & $\mathrm{SI} 3$ & & 0.790 & Valid & & & \\
\hline \multirow{4}{*}{$\begin{array}{l}\text { Performance } \\
\text { Expectancy } \\
\quad(\mathrm{PE})\end{array}$} & PE1 & \multirow{4}{*}{0.550} & 0.704 & Valid & \multirow{4}{*}{0.830} & \multirow{4}{*}{0.727} & \multirow{4}{*}{ Reliable } \\
\hline & PE2 & & 0.756 & Valid & & & \\
\hline & PE3 & & 0.795 & Valid & & & \\
\hline & PE4 & & 0.707 & Valid & & & \\
\hline \multirow{3}{*}{$\begin{array}{c}\text { Effort } \\
\text { Expectancy } \\
\text { (EE) }\end{array}$} & EE1 & \multirow{2}{*}{0.715} & 0.862 & Valid & \multirow{2}{*}{0.834} & \multirow[b]{2}{*}{0.603} & \multirow[b]{2}{*}{ Reliable } \\
\hline & EE2 & & 0.829 & Valid & & & \\
\hline & & & & & & & \\
\hline
\end{tabular}




\begin{tabular}{|c|c|c|c|c|c|c|c|}
\hline \multirow{4}{*}{$\begin{array}{l}\text { Facilitating } \\
\text { Condition } \\
\text { (FC) }\end{array}$} & $\mathrm{FC} 1$ & \multirow{4}{*}{0.546} & 0.662 & Valid & \multirow{4}{*}{0.827} & \multirow{4}{*}{0.724} & \multirow{4}{*}{ Reliable } \\
\hline & FC2 & & 0.797 & Valid & & & \\
\hline & FC3 & & 0.784 & Valid & & & \\
\hline & $\mathrm{FC} 4$ & & 0.705 & Valid & & & \\
\hline \multirow{2}{*}{$\begin{array}{l}\text { Behavioral } \\
\text { Intention } \\
\text { (BI) }\end{array}$} & BI1 & \multirow[b]{2}{*}{0.587} & 0.638 & Valid & \multirow[b]{2}{*}{0.735} & \multirow[b]{2}{*}{0.614} & \multirow[b]{2}{*}{ Reliable } \\
\hline & $\mathrm{BI} 2$ & & 0.876 & Valid & & & \\
\hline \multirow{3}{*}{$\begin{array}{l}\text { Use Behavior } \\
\text { (UB) }\end{array}$} & UB1 & \multirow{3}{*}{0.721} & 0882 & Valid & \multirow{3}{*}{0.837} & \multirow{3}{*}{0.616} & \multirow{3}{*}{ Reliable } \\
\hline & & & & & & & \\
\hline & UB2 & & 0.815 & Valid & & & \\
\hline
\end{tabular}

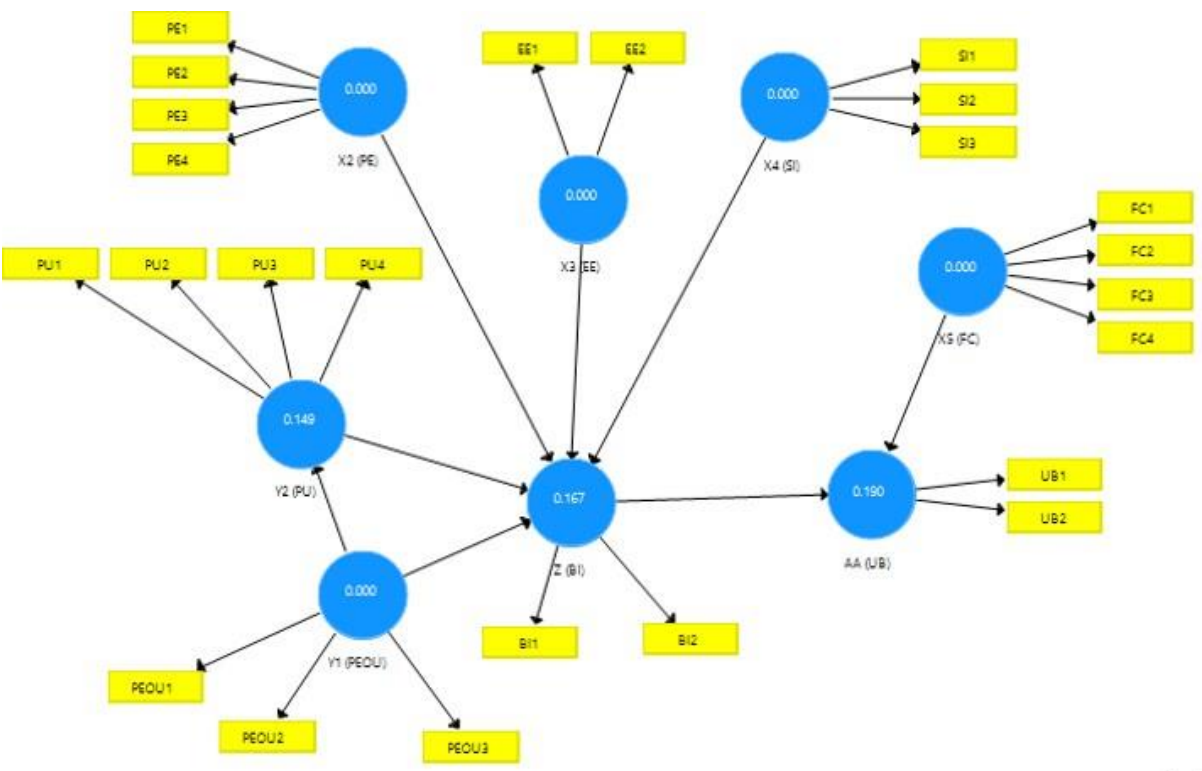

Figure 2 T-Value of Each Indicator

\subsection{Output Results}

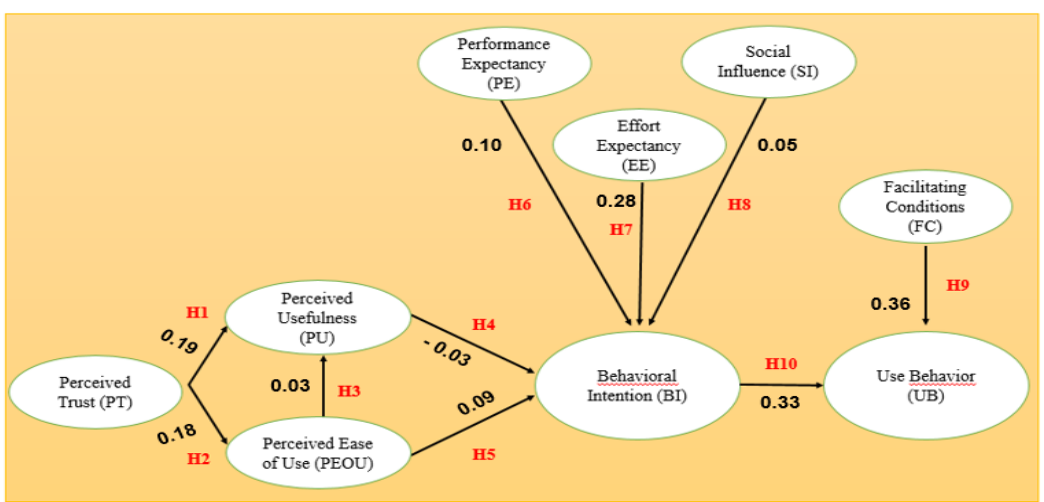

Figure 3 Output Results 


\subsubsection{Output Results}

The values obtained are as follows:

- $\quad$ H1 - Hypothesis Accepted: Perceived Trust (PT) has affects towards Perceived Ease of Use (PEOU) equal to $19 \%$. Which means that the influnce of this variable is quite low, and the remaining $81 \%$ is influenced by other variables.

- $\quad$ H2 - Hypothesis Accepted: Perceived Trust (PT) has effects towards Perceived Ease of Use (PEOU) equal to $18 \%$ (quite low - and remaining $82 \%$ is also influenced by other variables).

- $\quad \mathrm{H} 3, \mathrm{H} 4, \mathrm{H} 5$, and H8 - Hypothesis Rejected

- $\quad$ H7 - Hypothesis Accepted: Effort Expectancy (EE) has effects towards Behavioral Intention (BI) equal to $28 \%$, which means remaining $72 \%$ is influenced by other variables.

- $\quad$ H9 - Hypothesis Accepted: Facilitating Condition (FC) has the biggest effects towards Use Behavior (UB) equal to $\underline{36 \%}$. Can be categorized as a high influence percentage.

- H10 - Hypothesis Accepted: Behavioral Intention (BI) has effects towards Use Behavior (UB) equal to $33 \%$. Also can be categorized as a high influence percentage.

\section{Conclusion}

Endogenous variables have the greatest influence than other endogenous variables on the digital form mobile application of PT. ABC: Facilitating Condition (FC) variable with value 36\% (above 30\% can be categorized as high percentages, so company need to pay attention to this variable). Behavioral Intention (BI), which is an exogenous variable as well as a mediating variable, has the greatest influence on continuous use of the digital form mobile application at PT. ABC, by 33\% (also need to be considered because the percentage is quite high). Some of the benefits that can be obtained from this research are the implementation of a digital form mobile application in terms of guidance and fits into style for customers. $\mathrm{R}$ Square results indicate that the technology itself is not a determinant of the successful adoption rate of the use of the digital form mobile application (shown only $11 \%$ of technology factors that affect the behavior intention of its users). So it can be concluded that there are other factors outside of technology that affect the acceptance rate of the digital form mobile application at PT. ABC itself.

\section{Implication}

There were no significant difficulties with this study. The researcher can obtain the data and process them according to the research framework and concepts. Some theoritical and managerial implication suggestions that the researcher can give are as follows:

\subsection{Digital Service}

Accelerate additions to service features that are still inactive, especially in customer service and tellers, such as the option of overseas transactions, as well as remittances to other banks in order to accelerate traffic from banking transactions themselves.

\subsection{Promotion}

It is necessary to promote through social media (Facebook, Instagram etc) and printed media (newspaper, magazine, etc) about the presence and benefits of the digital form mobile application. As well as urge each customer to make transactions using the digital form mobile application continuously.

\subsection{Management}

There is potency for the application of e-Branch in the future, because the use of the digital form mobile application itself actually accelerates transaction activities and also saves time and paper usage. 


\section{References}

[1] Malhotra, Y., \& Galletta, D. F. (1999). Extending the Technology Acceptance Model to account for social influence: Theoretical bases and empirical validation. Proceedings of the Hawaii International Conference on System Sciences, 5. https://doi.org/10.1109/hicss.1999.772658

[2] Mardiana, S., Tjakraatmadja, J. H., \& Aprianingsih, A. (2015). DeLone-Mclean information system success model revisited: The separation of intention to Use - Use and the integration of technology acceptance models. International Journal of Economics and Financial Issues, 5, 172182.

[3] Kim, S., Lee, K. H., Hwang, H., \& Yoo, S. (2016). Analysis of the factors influencing healthcare professionals' adoption of mobile electronic medical record (EMR) using the unified theory of acceptance and use of technology (UTAUT) in a tertiary hospital. BMC Medical Informatics and Decision Making, 16(1). https://doi.org/10.1186/s12911-016-0249-8 